\title{
Hiding in Fresh Fruits and Vegetables: Opportunistic Pathogens May Cross Geographical Barriers
}

\author{
Zahra S. Al-Kharousi, ${ }^{1}$ Nejib Guizani, ${ }^{1}$ Abdullah M. Al-Sadi, ${ }^{2}$ \\ Ismail M. Al-Bulushi, ${ }^{1}$ and Baby Shaharoona ${ }^{3}$ \\ ${ }^{1}$ Department of Food Science \& Nutrition, College of Agricultural and Marine Sciences, Sultan Qaboos University, \\ P.O. Box 34, Al-Khod, 123 Muscat, Oman \\ ${ }^{2}$ Department of Crop Sciences, College of Agricultural and Marine Sciences, Sultan Qaboos University, \\ P.O. Box 34, Al-Khod, 123 Muscat, Oman \\ ${ }^{3}$ Department of Soils, Water and Agricultural Engineering, College of Agricultural and Marine Sciences, Sultan Qaboos University, \\ P.O. Box 34, Al-Khod, 123 Muscat, Oman
}

Correspondence should be addressed to Zahra S. Al-Kharousi; umohaned@squ.edu.om

Received 30 September 2015; Accepted 24 January 2016

Academic Editor: Susana Merino

Copyright (C) 2016 Zahra S. Al-Kharousi et al. This is an open access article distributed under the Creative Commons Attribution License, which permits unrestricted use, distribution, and reproduction in any medium, provided the original work is properly cited.

Different microbial groups of the microbiome of fresh produce can have diverse effects on human health. This study was aimed at identifying some microbial communities of fresh produce by analyzing 105 samples of imported fresh fruits and vegetables originated from different countries in the world including local samples (Oman) for aerobic plate count and the counts of Enterobacteriaceae, Enterococcus, and Staphylococcus aureus. The isolated bacteria were identified by molecular (PCR) and biochemical methods (VITEK 2). Enterobacteriaceae occurred in $60 \%$ of fruits and $91 \%$ of vegetables. Enterococcus was isolated from $20 \%$ of fruits and $42 \%$ of vegetables. E. coli and S. aureus were isolated from $22 \%$ and $7 \%$ of vegetables, respectively. Ninety-seven bacteria comprising 21 species were similarly identified by VITEK 2 and PCR to species level. E. coli, Klebsiella pneumoniae, Enterococcus casseliflavus, and Enterobacter cloacae were the most abundant species; many are known as opportunistic pathogens which may raise concern to improve the microbial quality of fresh produce. Phylogenetic trees showed no relationship between clustering of the isolates based on the 16S rRNA gene and the original countries of fresh produce. Intercountry passage of opportunistic pathogens in fresh produce cannot be ruled out, which requires better management.

\section{Introduction}

Being sources of high energy and rich in minerals, vitamins, fibers, and phenolics, fruits and vegetables constitute an important food group that has been linked to maintenance of well-being of individuals [1] and to reduced incidence of some chronic diseases [2]. In addition to the nutritional value of fresh produce, their diverse microbiomes can pass through stomach to the gut where they establish specific associations with the host resulting in various effects on human health [3]. Recently, interesting relationships have been found between gut microbiota and obesity, malnutrition, cancer, personal motivation, and decision-making in which microbial balance is critical for maintaining the healthy state $[3,4]$.
On the other hand, the increased consumption of fruits and vegetables in recent years has been found to be accompanied by an increase in the number of human infections and outbreaks [5] as these can serve as reservoirs for pathogens or opportunistic pathogens [3]. Fruits and vegetables can be contaminated with spoilage or pathogenic bacteria at any stage from production to consumption [6, 7]. Although their microflora is dominated by spoilage bacteria, yeasts, and molds, fruits and vegetables can harbor pathogenic bacteria such as Salmonella, Escherichia coli, Bacillus cereus, Campylobacter spp., Yersinia enterocolitica, Listeria monocytogenes, and Clostridium botulinum, as well as some viruses and parasites [6]. In Royal Hospital, Oman, May 2008, B. cereus caused a nosocomial outbreak with gastroenteritis 
and affected 58 individuals. B. cereus and its toxin were found in different foods including vegetables [8]. A more serious outbreak, May-July 2011, was caused by Shiga toxin producing E. coli O104:H4 in Germany where 2987 cases of gastroenteritis, 855 cases of hemolytic-uremic syndrome, and 53 deaths were reported. Fenugreek sprouts were found to be contaminated with the causative agent [9]. Bean sprouts were linked to two outbreaks in USA, in 2014; one was caused by L. monocytogenes in August while Salmonella Enteritidis caused the other one just a month later. L. monocytogenes was also involved in another outbreak that was linked to caramel apples in October 2014 in USA [10]. Opportunistic pathogens can cause life-threatening infections mainly in immunocompromised people but they may have positive effects on the health of immunocompetent individuals by stimulating immune functions and priming the immune system continuously [3]. Nonpathogenic microbes associated with fruits and vegetables may have various consequences on the quality of the produce by affecting the rate of the food spoilage. Fruits and vegetables seem also to be the sources that disseminate many microbes to food preparation areas [11].

In Oman, large quantities of fruits and vegetables are imported nearly from all around the world to provide a yearround supply [12] to this country which is located at the crossroads of the exchange of cultivated plants [13]. This study aims at assessing the microbial load of some fresh fruits and vegetables imported into or grown in Oman and to identify the isolated bacteria by biochemical and molecular methods with emphasis on emergent opportunistic pathogens. The study will also investigate genetic relationships between bacteria isolated from fruits and vegetables originated from different countries in the world. Findings from this study will provide information on the sanitary conditions of fruits and vegetables produced and consumed in this part of the world, which will help in improving their quality and safety for consumption. To our knowledge, this is the first report that analyzes microbial content of fresh produce in this country and also relates the presence of particular opportunistic pathogens isolated from different local and imported samples to particular effects on human health.

\section{Materials and Methods}

2.1. Sample Collection. Fruits and vegetables that are mostly eaten raw were selected for this study. These contained 7 types of fresh imported or locally produced fruits (banana, Musa spp.; dates, Phoenix dactylifera; mango, Mangifera indica; papaya, Carica papaya; pomegranate, Punica granatum; tomato, Solanum lycopersicum; and watermelon, Citrullus lanatus) and 6 types of fresh imported or locally produced vegetables (cabbage, Brassica oleracea; capsicum, Capsicum annuum; carrot, Daucus carota; cucumber, Cucumis sativus; lettuce, Lactuca sativa; and radish, Raphanus sativus). Samples were purchased from local markets in Muscat or Nizwa, Oman, during the period of April to September 2014. The imported fruits and vegetables originated from different countries and they were selected depending on their availability in the market during that period of time. Three samples were obtained for each fruit or vegetable type originated from the same country. The samples were collected aseptically and refrigerated until analyzed within 24 hrs. Table 1 represents the origin of all samples.

\subsection{Microbiological Analysis of Fruits and Vegetables}

2.2.1. Sample Preparation, Aerobic Plate Count, and Selective Bacterial Counts. Samples were analyzed in a safety cabinet (Purifier class II, Labconco, Kansas, USA) and cut using sterile scalpels. Some fruits (banana, mango, papaya, pomegranate, and watermelon) were peeled and the inside flesh was analyzed. Twenty-five grams of the cut sample was weighed in a sterile stomacher bag and mixed with $225 \mathrm{~mL}$ of Maximum Recovery Diluent (MRD) and homogenized for $1 \mathrm{~min}$ using a stomacher (Bagmixer 100 MiniMix, Interscience, Bois Arpents, France). Serial dilutions were prepared from the original homogenate in MRD. Aerobic plate count (APC) was performed by spread plate method. The plates of standard plate count agar (SPCA) were incubated at $35^{\circ} \mathrm{C}$ for $48 \mathrm{hrs}$ [7]. The count of Enterobacteriaceae was performed on Violet Red Bile Glucose (VRBG) agar by pour plate method and incubation at $35^{\circ} \mathrm{C}$ for $24 \mathrm{hrs}$. E. coli was counted on Tryptone Bile X-glucuronide (TBX) medium and the plates were incubated at 2 temperatures: 30 and $44^{\circ} \mathrm{C}$ for $24 \mathrm{hrs}$ [14]. Staphylococcus aureus was counted on Baird-Parker (BP) agar after incubation at $35^{\circ} \mathrm{C}$ for $24 \mathrm{hrs}$ [7]. Enterococcus was counted on Slanetz agar after incubation at $35^{\circ} \mathrm{C}$ for $48 \mathrm{hrs}$ [15]. All microbiological media were from Oxoid, England, and all experiments were repeated three times.

2.2.2. Identification of Bacteria. For each selective medium (BPA, VRBG, TBX, and Slanetz agar), one bacterial isolate showing the typical morphology (details could be found by searching manufacturer's website (http://www.oxoid.com/ UK/blue/index.asp?c=UK\&lang=EN)) was selected from each sample for identification. Bacteria were preserved at $-80^{\circ} \mathrm{C}$ using cryogenic vials with beads (Viabank, UK).

(1) Identification of Bacteria by VITEK 2. Identification of bacteria using biochemical tests was done using an automated identification equipment; VITEK 2-compact 15 (bioMérieux, France) following instructions of the manufacturer. In brief, bacterial suspensions were prepared in sterile saline $(0.45 \%)$ and the density was adjusted to a McFarland standard of 0.5-0.63 using VITEK 2 DensiCheck (bioMérieux, France). GP and GN cards were used for Gram-positive and Gramnegative bacteria, respectively.

(2) Identification of Bacteria by Polymerase Chain Reaction (PCR). The second method was performed using polymerase chain reaction (PCR) targeting bacterial 16S rRNA [16]. Briefly, DNA was extracted using "foodproof StarPrep Two Kit" (Biotecon Diagnostics GmbH, Potsdam, Germany). The quality and quantity of DNA were checked using NanoDrop $^{\text {тu }} 2000$ (Thermoscientific, USA). PCR was done by transferring $1 \mu \mathrm{L}$ of each primer (27F and 1492R; DNA sequences: $5^{\prime}$-AGAGTTTGATCMTGGCTCAG- $3^{\prime}$ and $5^{\prime}$ TACGGYTACCTTGTTACGACTT-3', resp.), $22 \mu \mathrm{L}$ of sterile 
TABLE 1: Origin of fruits and vegetables and the number of positive samples for different microbial counts.

\begin{tabular}{|c|c|c|c|c|c|c|c|c|}
\hline Number & Type of produce & Origin* & APC & Enterobacteriaceae & S. aureus & Enterococcus & E. $\operatorname{coli}\left(30^{\circ} \mathrm{C}\right)$ & E. $\operatorname{coli}\left(44^{\circ} \mathrm{C}\right)$ \\
\hline & Fruit $(n=60)$ & & & & & & & \\
\hline \multirow{2}{*}{1} & \multirow{2}{*}{ Banana } & Oman & 3 & 3 & 0 & 0 & 0 & 0 \\
\hline & & Philippine & 3 & 2 & 0 & 0 & 0 & 0 \\
\hline \multirow{2}{*}{2} & \multirow{2}{*}{ Dates } & Oman & 3 & 3 & 0 & 1 & 0 & 0 \\
\hline & & Saudi Arabia & 3 & 2 & 0 & 1 & 0 & 0 \\
\hline \multirow{2}{*}{3} & \multirow{2}{*}{ Mango } & Oman & 3 & 3 & 0 & 1 & 0 & 0 \\
\hline & & India, Pakistan & 3,3 & 1,1 & 0,0 & 0,0 & 0,0 & 0,0 \\
\hline \multirow{2}{*}{4} & \multirow{2}{*}{ Papaya } & Oman & 3 & 3 & 0 & 3 & 0 & 0 \\
\hline & & Thailand, Philippine & 3,3 & 3,3 & 0,0 & 0,0 & 0,0 & 0,0 \\
\hline \multirow{2}{*}{5} & \multirow{2}{*}{ Pomegranate } & Oman & 1 & 0 & 0 & 0 & 0 & 0 \\
\hline & & India, Saudi Arabia & 2,3 & 0,0 & 0,0 & 0,0 & 0,0 & 0,0 \\
\hline \multirow{2}{*}{6} & \multirow{2}{*}{ Tomato } & Oman & 3 & 3 & 0 & 0 & 0 & 0 \\
\hline & & Jordan, Netherlands, Syria & $2,1,3$ & $0,1,3$ & $0,0,0$ & $0,0,2$ & $0,0,0$ & $0,0,0$ \\
\hline \multirow{2}{*}{7} & \multirow{2}{*}{ Watermelon } & Oman & 3 & 1 & 0 & 1 & 0 & 0 \\
\hline & & Egypt, Iran & 3,3 & 2,3 & 0,0 & 0,3 & 0,0 & 0,0 \\
\hline \multirow{3}{*}{1} & \multicolumn{8}{|l|}{ Vegetable $(n=45)$} \\
\hline & Cabbage & Oman & 3 & 3 & 0 & 3 & 3 & 3 \\
\hline & eavoda & Netherlands & 3 & 3 & 0 & 3 & 0 & 0 \\
\hline \multirow{2}{*}{2} & \multirow{2}{*}{ Carrot } & Oman & 3 & 3 & 0 & 0 & 0 & 0 \\
\hline & & Australia, USA & 3,3 & 3,3 & 0,0 & 0,0 & 0,0 & 0,0 \\
\hline \multirow{2}{*}{3} & \multirow{2}{*}{ Capsicum } & Oman & 3 & 2 & 0 & 0 & 0 & 0 \\
\hline & & Jordan, UAE & 3,3 & 3,2 & 0,0 & 0,0 & 0,0 & 0,0 \\
\hline \multirow{2}{*}{4} & \multirow{2}{*}{ Cucumber } & Oman & 3 & 3 & 0 & 0 & 0 & 0 \\
\hline & & UAE & 3 & 3 & 0 & 1 & 0 & 0 \\
\hline \multirow{2}{*}{5} & \multirow{2}{*}{ Lettuce } & Oman & 3 & 3 & 0 & 1 & 0 & 0 \\
\hline & & Iran, Jordan & 3,3 & 3,1 & 0,0 & 3,3 & 0,1 & 0,2 \\
\hline \multirow{2}{*}{6} & \multirow{2}{*}{ Radish } & Oman & 3 & 3 & 3 & 3 & 3 & 1 \\
\hline & & China & 3 & 3 & 0 & 3 & 1 & 1 \\
\hline
\end{tabular}

APC: aerobic plate count, USA: United States of America, and UAE: United Arab Emirates.

${ }^{*}$ Three samples were analyzed from each country.

milliQ water, and $1 \mu \mathrm{L}$ of the DNA sample to PCR reaction tubes containing PCR beads (puReTaq Ready-To-Go PCR beads, GE Healthcare, UK). The thermal profile (Veriti 96well Thermal cycler, Applied Biosystems, Singapore) for PCR reaction was as follows: denaturation at $95^{\circ} \mathrm{C}$ for $2 \mathrm{~min}$, followed by 35 cycles of denaturation at $95^{\circ} \mathrm{C}$ for $30 \mathrm{sec}$, annealing at $54^{\circ} \mathrm{C}$ for $30 \mathrm{sec}$, and extension at $72^{\circ} \mathrm{C}$ for $1 \mathrm{~min}$. The final extension was at $72^{\circ} \mathrm{C}$ for $10 \mathrm{~min}$ and then kept at $4^{\circ} \mathrm{C}$. Aliquots of PCR products were checked by subjecting them to $1.5 \%$ agarose gel electrophoresis and viewing them by GelDoc. PCR products were sent for sequencing at Macrogen (Korea) using the same primers used for amplification. The sequencing results were compared with those found at the National Center for Biotechnology Information (NCBI) using BLAST search. Then, sequences of reference isolates of each bacterial species were obtained from GenBank and neighbor joining trees were constructed for each bacterial group/genus using the Kimura 2 parameter evolutionary model (Mega 5) [17]. Then bootstrap 50\% majority-rule consensus trees were generated (1000 replications).
2.3. Statistical Methods. Two-way analysis of variance (ANOVA) was used to determine if aerobic plate counts and Enterobacteriaceae counts varied significantly between different types of fruits/vegetables and between local and imported fruits/vegetables. Data Disk 6.1 (Data Description, Inc., New York, USA) was used to perform the statistical tests to identify any significant differences which were considered as $P<0.05$.

\section{Results}

3.1. Bacterial Counts. The origin and number of positive samples of fruits and vegetables are shown in Table 1 while Figure 1 shows the counts of different bacterial groups in different fruits and vegetables used in this study. Aerobic plate count (APC) of local fruits (LF) (mean $\left.=6.1 \log \mathrm{CFU} \mathrm{g}^{-1}\right)$ was significantly greater than APC of imported fruits (IF) $\left(\right.$ mean $\left.=5.0 \log \mathrm{CFU} \mathrm{g}^{-1}\right)$ (ANOVA, $\left.P=0.0227, \alpha=0.05\right)$ but APC was not significantly different between local vegetables $(\mathrm{LV})\left(\right.$ mean $=6.3 \log \mathrm{CFU} \mathrm{g}^{-1}$ ) and imported vegetables (IV) 


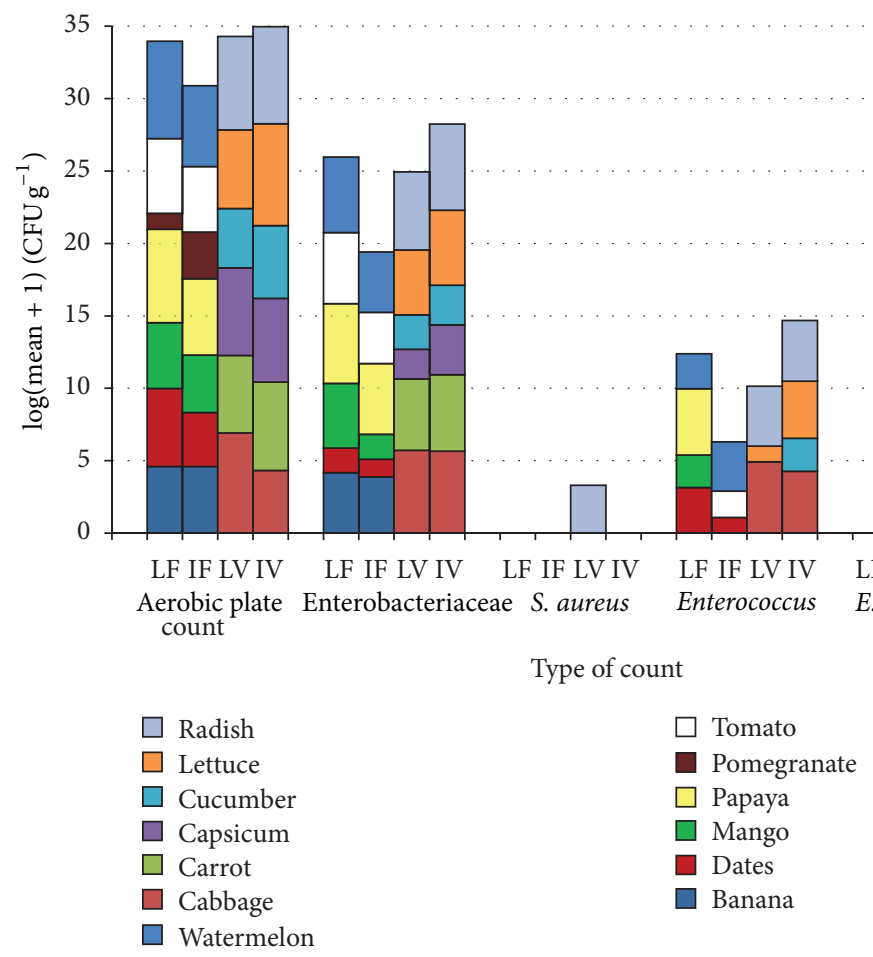

Figure 1: Microbial counts $\left(\log (\right.$ mean +1$\left.) \mathrm{CFU} \mathrm{g}^{-1}\right)$ in local fruits $(\mathrm{LF})$, imported fruits (IF), local vegetables (LV), and imported vegetables (IV).

$\left(\right.$ mean $\left.=6.5 \log \mathrm{CFU} \mathrm{g}^{-1}\right)($ ANOVA, $P=0.2046, \alpha=0.05)$. APC differed significantly between the different types of fruits (ANOVA, $P=0.0001, \alpha=0.05$ ) and vegetables (ANOVA, $P=$ $0.0035, \alpha=0.05)$. Enterobacteriaceae and Enterococcus were found in all groups that were tested, LF, IF, LV, and IV while $S$. aureus was found only in LV (radish). E. coli was isolated from LV and IV but not from any fruit (Figure 1). Fifteen samples (71.4\%, $n=21$ ) of the locally produced fruits were positive for Enterobacteriaceae $\left(\right.$ mean $\left.=4.9 \log \mathrm{CFU} \mathrm{g}^{-1}\right)$ while about half $(53.8 \%, n=39)$ of the imported fruits were positive for Enterobacteriaceae $\left(\right.$ mean $\left.=4.2 \log \mathrm{CFU} \mathrm{g}^{-1}\right)$. Seventeen samples $(94.4 \%, n=18)$ of the local vegetables were positive for Enterobacteriaceae $\left(\right.$ mean $=5.2 \log \mathrm{CFU} \mathrm{g}^{-1}$ ) while 24 samples $(88.9 \%, n=27)$ of the imported vegetables were positive $\left(\right.$ mean $\left.=5.3 \log \mathrm{CFU} \mathrm{g}^{-1}\right)$. The count of Enterobacteriaceae in LF was significantly greater than the count in IF (ANOVA, $P=0.0011, \alpha=0.05$ ) but it did not differ significantly between LV and IV (ANOVA, $P=0.2029$, $\alpha=0.05)$. The count of Enterobacteriaceae was significantly different from one type of fruit to another (ANOVA, $P=$ $0.0001, \alpha=0.05)$ as well as among different types of vegetables (ANOVA, $P=0.0001, \alpha=0.05$ ).

At $30^{\circ} \mathrm{C}, \mathrm{E}$. coli was isolated from $6 \mathrm{LV}$ (3 cabbages and 3 radishes, mean $=3.8 \log \mathrm{CFU} \mathrm{g}^{-1}$ ) and from $2 \mathrm{IV}$ samples (lettuce and radish, mean $=1.9 \log \mathrm{CFU} \mathrm{g}^{-1}$ ) while at $44^{\circ} \mathrm{C}$ E. coli was isolated from $4 \mathrm{LV}$ samples (3 cabbages and 1 radish, mean $\left.=3.1 \log \mathrm{CFU} \mathrm{g}^{-1}\right)$ and from $3 \mathrm{IV}$ samples $(2$ lettuces and 1 radish, mean $\left.=0.4 \log \mathrm{CFU} \mathrm{g}^{-1}\right)$. Enterococcus was found in $6 \mathrm{LF}\left(28.6 \%\right.$, mean $\left.=3.8 \log \mathrm{CFU} \mathrm{g}^{-1}\right)$,
$6 \operatorname{IF}\left(15.4 \%\right.$, mean $\left.=2.6 \log \mathrm{CFU} \mathrm{g}^{-1}\right), 7 \mathrm{LV}(38.9 \%$, mean $=$ $\left.4.2 \log \mathrm{CFU} \mathrm{g}^{-1}\right)$, and $13 \mathrm{IV}\left(48.1 \%\right.$, mean $\left.=3.8 \log \mathrm{CFU} \mathrm{g}^{-1}\right)$. $S$. aureus was isolated only from 3 local radish samples (mean $=2.5 \log \mathrm{CFU} \mathrm{g}^{-1}$ ).

3.2. Identification of Bacteria. Out of 130 bacteria (numbered from 1-130) that were isolated from fresh fruits and vegetables (except 4 reference strains, numbers 127-130), a total of $97(74.6 \%)$ isolates (21 species) were similarly identified by VITEK 2 and PCR to species level (Table 2). The most encountered species was E. coli (15 isolates) followed by Klebsiella pneumoniae and Enterococcus casseliflavus (13 isolates each) and then Enterobacter cloacae (12 isolates). Thirtythree bacteria were not similarly identified to species level by VITEK 2 and PCR (Table 3). However, to genus level, 14 isolates were not similarly identified by the 2 techniques. The differences in identification at genus level were only among isolates of Enterobacteriaceae. The 16S rRNA gene sequences of bacteria numbers 1-130 were sequentially given accession numbers of KR265345-KR265474 by the GenBank.

3.3. Phylogenetic Analysis. Phylogenetic analysis showed grouping of most bacterial isolates with the reference species obtained from NCBI, except for few isolates from the Enterobacteriaceae. K. pneumoniae and $R$. aquatilis made distinct clear clusters while other isolates belonging to Enterobacteriaceae made several groups (Figure 2). E. coli isolates grouped into two clusters, (bootstrap values: 66$86 \%$; Figure 3). However, there was no relationship between 
TABLE 2: Bacteria that were similarly identified to species level by VITEK 2 and PCR and their sources.

\begin{tabular}{|c|c|c|c|}
\hline Name of bacteria & Number of isolates & Rank & Source \\
\hline Citrobacter freundii & 1 & 13 & Tomato (Netherlands) \\
\hline Enterobacter amnigenus & 4 & 7 & Carrot (USA), lettuce (Oman), radish (China) \\
\hline Enterobacter asburiae & 1 & 13 & Carrot (Oman) \\
\hline Enterobacter cloacae & 12 & 4 & $\begin{array}{l}\text { Cabbage, carrot, papaya, radish, watermelon (Oman), } \\
\text { lettuce (Iran), papaya (Philippines), papaya (Thailand), } \\
\text { tomato (Syria), watermelon (Egypt) }\end{array}$ \\
\hline Enterobacter hormaechei & 1 & 13 & Tomato (Syria) \\
\hline Enterobacter ludwigii & 3 & 8 & Capsicum, cucumber (UAE), tomato (Oman) \\
\hline Enterococcus casseliflavus & 13 & 2 & $\begin{array}{l}\text { Cabbage (Netherlands), cucumber (UAE), dates (Saudi } \\
\text { Arabia), lettuce (Iran), radish (China), tomato ( Syria), } \\
\text { watermelon (Iran), watermelon (Oman) }\end{array}$ \\
\hline Enterococcus faecalis & 7 & 5 & $\begin{array}{l}\text { Lettuce (Jordan), lettuce (Iran), radish, mango, papaya } \\
\text { (Oman) }\end{array}$ \\
\hline Enterococcus faecium & 2 & 11 & Cabbage (Oman), lettuce (Jordan) \\
\hline Enterococcus hirae & 1 & 13 & Papaya (Oman) \\
\hline Enterococcus raffinosus & 1 & 13 & Dates (Oman) \\
\hline Escherichia coli & 15 & 1 & $\begin{array}{l}\text { Cabbage, radish (Oman), lettuce (Jordan), radish } \\
\text { (China) }\end{array}$ \\
\hline Klebsiella oxytoca & 2 & 11 & Radish (China), tomato (Oman) \\
\hline Klebsiella pneumoniae & 13 & 2 & $\begin{array}{l}\text { Cabbage (Oman), capsicum (Jordan), banana } \\
\text { (Philippines), dates (Oman), mango (Oman), papaya } \\
\text { (Oman), watermelon (Iran) }\end{array}$ \\
\hline Kluyvera intermedia & 1 & 13 & Cabbage (Netherlands) \\
\hline Pantoea agglomerans & 7 & 5 & $\begin{array}{l}\text { Cabbage (Netherlands), carrot (Australia), carrot } \\
\text { (USA), capsicum (UAE), lettuce (Jordan), radish } \\
\text { (China), watermelon (Iran) }\end{array}$ \\
\hline Rahnella aquatilis & 3 & 8 & Carrot (Australia), lettuce (Iran) \\
\hline Raoultella planticola & 1 & 13 & Cabbage (Netherlands) \\
\hline Serratia liquefaciens & 1 & 13 & Carrot (USA) \\
\hline Serratia marcescens & 1 & 13 & Tomato (Oman) \\
\hline Staphylococcus aureus & 3 & 8 & Radish (Oman) \\
\hline \multicolumn{4}{|l|}{ Reference strains } \\
\hline Staphylococcus aureus & 1 & & ATCC 29213 \\
\hline Staphylococcus aureus & 1 & & ATCC 25923 \\
\hline Escherichia coli & 1 & & ATCC 25922 \\
\hline Enterococcus faecalis & 1 & & ATCC 29212 \\
\hline Total & 97 & & \\
\hline
\end{tabular}

clustering of isolates and the countries or commodities from which they were obtained. The 5 isolates (including 2 reference strains) of $S$. aureus also grouped together with a very high bootstrap support (100\%; Figure 4). Enterococcus species grouped into different clusters (50-100\% bootstrap support; Figure 5). There was also no relationship between clustering of isolates of the Enterococcus species and the countries or commodities from which they were obtained (Figure 5).

\section{Discussion}

Most studies report the presence of pathogens in fruits and vegetables but the counts are rarely documented [5].
APC can be used to monitor the hygienic quality of a product throughout processing and distribution [18] but it is difficult to be used to draw a conclusion on the safety of a product [19]. Nevertheless, some researchers [20] found a strong association between APC and presence of E. coli in beef carcasses where $88 \%$ of samples having APC of $\geq 4 \log \mathrm{CFU} / \mathrm{cm}^{2}$ were positive for $E$. coli while only $21 \%$ of samples having APC of $<2 \log \mathrm{CFU} / \mathrm{cm}^{2}$ were positive. In this study, E. coli was isolated only from vegetable samples (from local cabbage and radish and from imported lettuce and radish) all with mean $\mathrm{APC} \geq 6.5 \log \mathrm{CFU} \mathrm{g}^{-1}$ (Figure 1). It is possible that a certain association does exist between APC and a particular pathogen but it depends on the type of a product and needs a large number of samples to be tested. 
TABLE 3: Bacteria that were not similarly identified to species level by VITEK and PCR and their sources.

\begin{tabular}{|c|c|c|c|}
\hline Number of strains & VITEK & PCR & Source \\
\hline 20 & Enterococcus faecium or E. gallinarum ${ }^{*}$ & Enterococcus mundtii & Cabbage (Oman) \\
\hline 21 & Enterococcus cecorum or Leuconostoc pseudomesenteroides* & Enterococcus sulfureus & Cabbage (Oman) \\
\hline 27 & Enterococcus cecorum or Leuconostoc pseudomesenteroides* & Enterococcus sulfureus & Lettuce (Jordan) \\
\hline 31 & Enterococcus faecium or E. gallinarum ${ }^{*}$ & Enterococcus mundtii & Lettuce (Iran) \\
\hline 33 & Enterococcus faecium or E. gallinarum ${ }^{*}$ & Enterococcus mundtii & Radish (Oman) \\
\hline 36 & Enterococcus faecium or E. gallinarum* & Enterococcus mundtii & Radish (China) \\
\hline 45 & Enterococcus raffinosus & Enterococcus gilvus & Tomato (Syria) \\
\hline 58 & Klebsiella pneumoniae ssp. pneumoniae & Klebsiella oxytoca & Carrot (Oman) \\
\hline 65 & Pantoea spp. or Aeromonas sobria* & Pantoea agglomerans & Capsicum (Oman) \\
\hline 66 & Pantoea spp. & Pantoea agglomerans & Capsicum (Oman) \\
\hline 67 & Pantoea spp. & Erwinia aphidicola & Capsicum (Jordan) \\
\hline 69 & Pantoea spp. & Erwinia aphidicola & Capsicum (Jordan) \\
\hline 72 & Ewingella americana or Pantoea spp.* & Pantoea dispersa & Cucumber (Oman) \\
\hline 73 & Pantoea spp. & Pantoea dispersa & Cucumber (Oman) \\
\hline 74 & Pantoea spp. & Pantoea dispersa & Cucumber (Oman) \\
\hline 76 & Pantoea spp. & Erwinia aphidicola & Cucumber (UAE) \\
\hline 77 & Pantoea spp. & Erwinia rhapontici & Cucumber (UAE) \\
\hline 80 & Leclercia adecarboxylata & Enterobacter cancerogenus & Lettuce (Oman) \\
\hline 83 & Pantoea spp. & Enterobacter cloacae & Lettuce (Iran) \\
\hline 85 & Pantoea spp. & Pectobacterium carotovorum & Radish (Oman) \\
\hline 87 & Pantoea spp. & Enterobacter cloacae & Radish (Oman) \\
\hline 91 & Serratia ficaria & Pantoea dispersa & Banana (Oman) \\
\hline 92 & Pantoea spp. & Pantoea cypripedii & Banana (Oman) \\
\hline 98 & Enterobacter cloacae complex ${ }^{* *}$ & Enterobacter oryzae & Dates (Saudi Arabia) \\
\hline 99 & Pantoea spp. & Pantoea agglomerans & Dates (Saudi Arabia) \\
\hline 100 & Pantoea spp. & Pseudocitrobacter faecalis & Mango (Oman) \\
\hline 103 & Pantoea spp. & Pantoea dispersa & Mango (India) \\
\hline 104 & Pantoea spp. & Pantoea dispersa & Mango (Pakistan) \\
\hline 108 & Pantoea spp. & Pantoea eucrina & Papaya (Thailand) \\
\hline 109 & Pantoea spp. & Pantoea dispersa & Papaya (Thailand) \\
\hline 112 & Pantoea spp. & Escherichia hermannii & Papaya (Philippines) \\
\hline 113 & Pantoea spp. & Enterobacter cloacae & Papaya (Philippines) \\
\hline 118 & Pantoea spp. & Pantoea vagans & Tomato (Syria) \\
\hline
\end{tabular}

${ }^{*}$ Low discrimination organisms (same biopattern was produced by the tested strains). ${ }^{* *}$ Slash line: biopattern is the same for these organisms: Enterobacter kobei, E. hormaechei, E. cloacae ssp. cloacae, E. cloacae ssp. dissolvens, or E. ludwigii.

In the current study, vegetables showed slightly larger APCs than fruits (range of mean count $=4.1-7.0$ and 1.1$6.7 \log \mathrm{CFU} \mathrm{g}^{-1}$, resp.). Vegetables are usually grown closer to soil than fruits and thus might be contaminated easily from soil [21]. In addition, some fruits that were observed to be physically contaminated with soil (watermelon) or deposited with dust (papaya) showed high APC counts of $\geq 6 \log \mathrm{CFU} \mathrm{g}{ }^{-1}$. Leafy vegetables were reported to give greater APC than nonleafy vegetables [7]. The highest microbial counts were obtained from the APC of leafy vegetables, imported lettuce $\left(\right.$ mean $=7.0 \log \mathrm{CFU} \mathrm{g}^{-1}$ ) followed by local cabbage (mean $=6.9 \log \mathrm{CFU} \mathrm{g}^{-1}$ ). This is $1 \log$ less than the maximum APC $\left(8 \log \mathrm{CFU} \mathrm{g}^{-1}\right)$ that was reported in cantaloupe, spinach, and lettuce in Saudi Arabia [7] but their maximum Enterobacteriaceae count of $4 \log \mathrm{CFU} \mathrm{g}^{-1}$ (cabbage and lettuce) was about 2 logs less than what was found in the current study (papaya, cabbage, and radish) (Figure 1). Pomegranate was found to be the least contaminated fruit having APC of 1.1 and $3.2 \log \mathrm{CFU} \mathrm{g}^{-1}$ (local and imported, resp.) with none of the other sought bacterial groups being detected. Pomegranate juice [2] and extracts [22, 23] were shown to possess antibacterial activity but the low $\mathrm{pH}$ of about 3.5 of pomegranate [24] might also have contributed to this inhibitory activity.

Clinically, many members of the family of Enterobacteriaceae are among the most potent and prevalent pathogens [25]; indeed, many of them have acquired resistance to most antibiotics [21]. Once ingested, antibiotic resistance genes, 


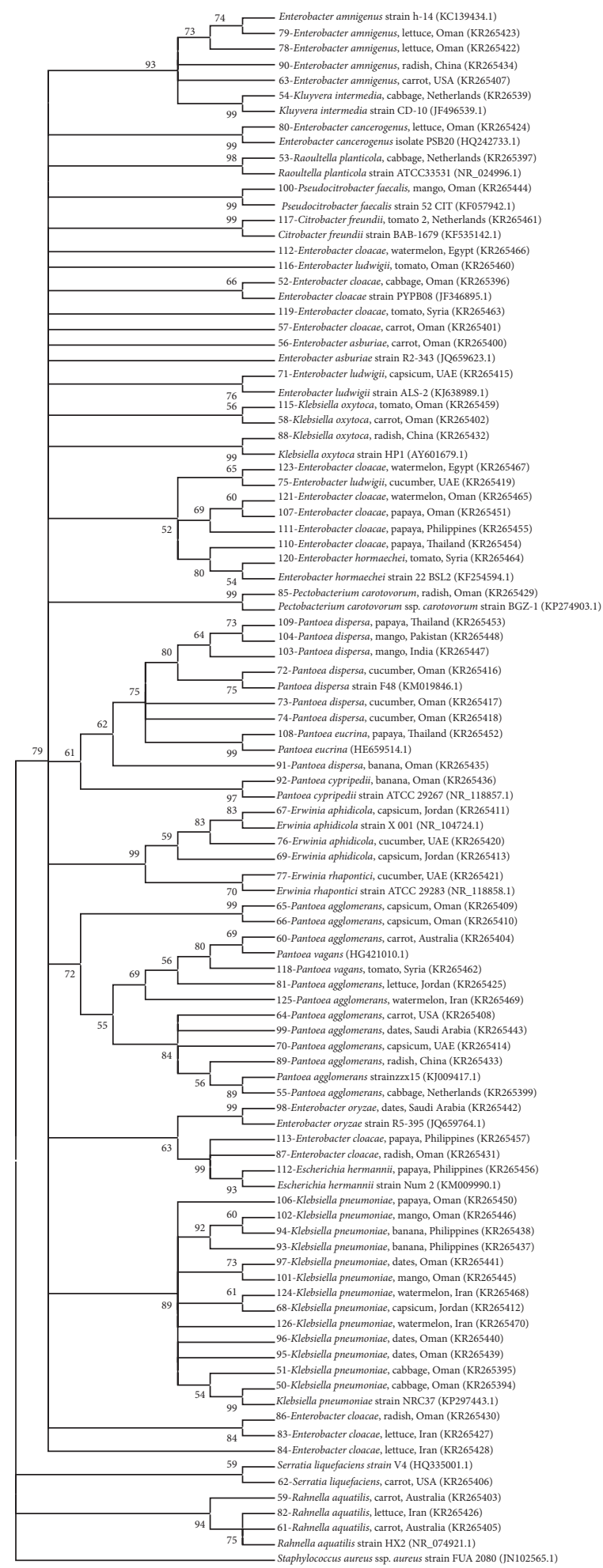

FIGURE 2: Neighbor joining tree based on 16S rRNA gene sequences of members of Enterobacteriaceae isolated from fresh produce. Staphylococcus aureus (JN102565) was included as an outgroup. KR-accession numbers correspond to gene sequences that belong to isolates analyzed in this study while others were obtained from NCBI database. Bootstrap values above 50\% are shown (1000 replications). 


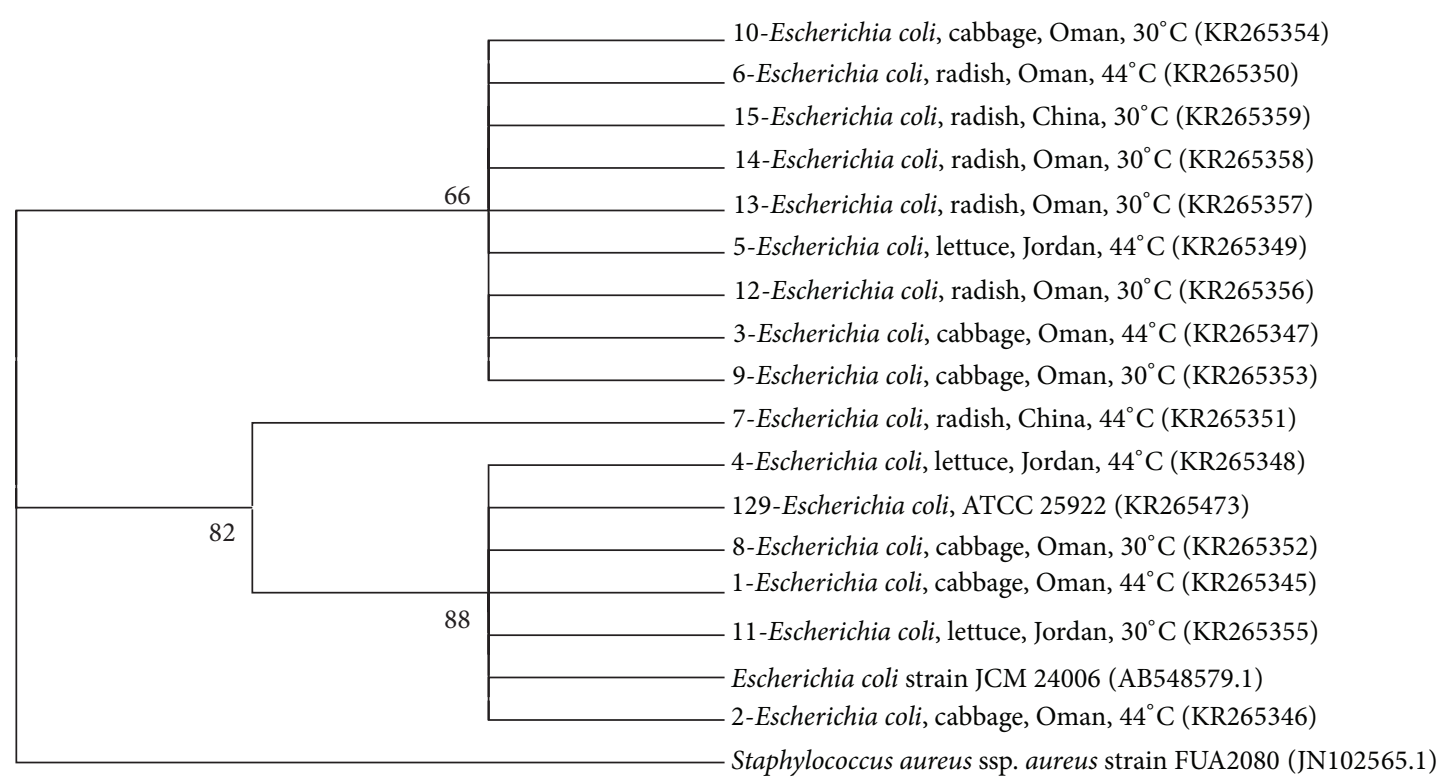

FIGURE 3: Neighbor joining tree based on $16 \mathrm{~S}$ rRNA gene sequences of E. coli isolated from fresh produce. E. coli strain JCM 24006 (AB548579) was included as a reference strain and Staphylococcus aureus (JN102565) was included as an outgroup. KR-accession numbers correspond to gene sequences that belong to isolates analyzed in this study while AB548579 and JN102565 were obtained from the NCBI database. Bootstrap values above $50 \%$ are shown (1000 replications).

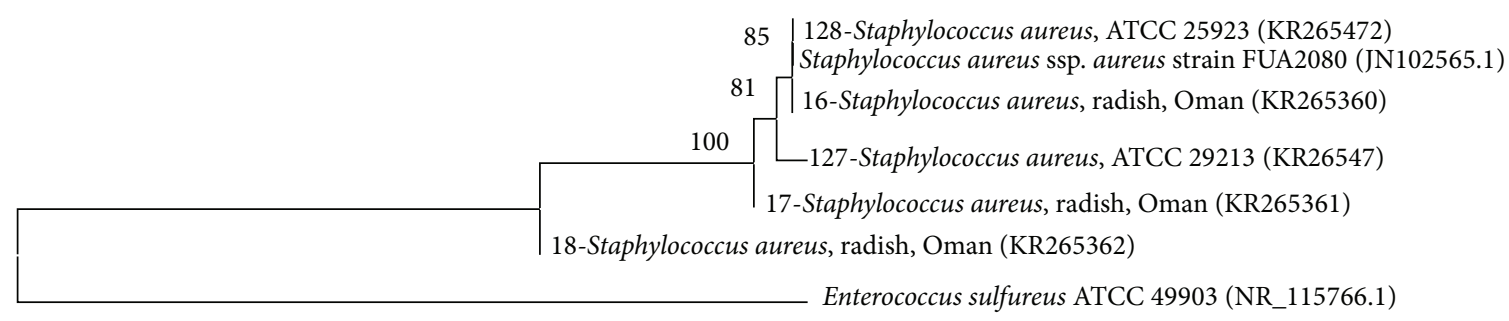

FIGURE 4: Neighbor joining tree based on 16S rRNA gene sequences of Staphylococcus aureus isolated from local radish. Enterococcus sulfureus ATCC 49903 (NR115766) was included as an outgroup. KR-accession numbers correspond to gene sequences that belong to isolates analyzed in this study while others were obtained from NCBI database. Bootstrap values above $50 \%$ are shown (1000 replications).

if present, may be transferred to the normal flora of the human gut and thus possibly to the pathogenic bacteria [26] especially if these resistance determinants can persist in the human gut for as long as a year as was proposed by Forslund and colleagues [27]. Many outbreaks in association with consumption of fresh produce are due to bacteria belonging to Enterobacteriaceae. Outbreaks that were linked to Salmonella Poona in cucumbers, S. Enteritidis in bean sprouts, E. coli O121 in raw clover sprouts, in 2014, and E. coli $\mathrm{O} 157: \mathrm{H7}$ in ready-to-eat salads in 2013 are just some examples [10]. The normal flora of many fruits and vegetables contains bacteria within the group of Enterobacteriaceae that might be present at high counts [28]. Our results showed that the counts of Enterobacteriaceae were comparable to APCs (Figure 1) and only pomegranate was free from bacteria belonging to this family (Table 1 ). A total of 15 species of Enterobacteriaceae were similarly identified by VITEK 2 and PCR (Table 2). In addition, 11 other species within this group were identified by PCR but not by VITEK 2 (Table 3 ). The 3 genera of Erwinia, Pectobacterium, and Pseudocitrobacter are not included in the most updated version (7.01) of the VITEK 2 identification database by GN card (isolates numbers 67 , $69,76,77,85$, and 100) and 6 other isolates could have been misidentified at genus level by VITEK 2 as compared to PCR (isolates numbers $80,83,87,91,112$, and 113) though these genera are included in VITEK 2 database. Within this group, 5 species of the similarly identified genera by VITEK 2 and PCR are not included in VITEK 2 latest version database including Pantoea dispersa (isolates numbers 72, 73, 74, 103, 104, and 109), Pantoea cypripedii (isolate number 92), Enterobacter oryzae (isolate number 98), Pantoea eucrina (isolate number 108 ), and Pantoea vagans (isolate number 118).

The genus of Klebsiella harbors opportunistic pathogens capable of causing severe infections [29]. Klebsiella pneumoniae was one of the most dominant species in this study and was isolated from local cabbage, dates, mango, and papaya and from imported capsicum (Jordan), banana (Philippine), and watermelon (Iran). Pantoea agglomerans (formerly Enterobacter agglomerans) and Rahnella aquatilis are opportunistic pathogens as well [30]. The genus of Enterobacter is one of 


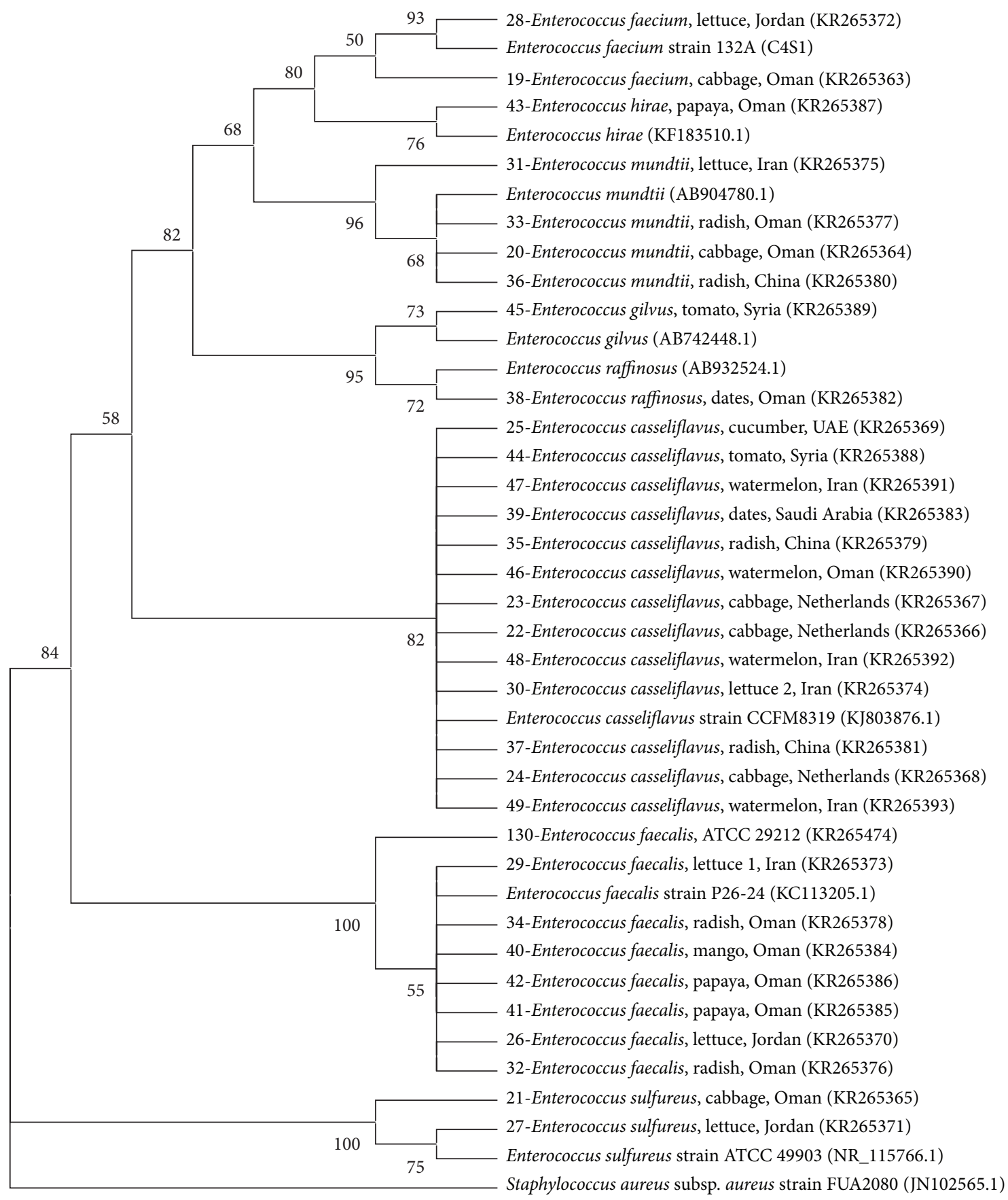

FIGURE 5: Neighbor joining tree based on sequencing 16S rRNA gene for members of Enterococcus isolated from fresh produce. Staphylococcus aureus (JN102565) was included as an outgroup. KR-accession numbers correspond to gene sequences that belong to isolates analyzed in this study while others were obtained from NCBI database. Bootstrap values above $50 \%$ are shown (1000 replications).

the largest genera in the family Enterobacteriaceae having at least 19 species. It also shows polyphyletic patterns when phylogenetic trees are constructed based on 16S rRNA sequences [31]. Many species within the genus of Enterobacter have been marked as emerging pathogens [30]. Pseudocitrobacter is a new genus in the family of Enterobacteriaceae and Pseudocitrobacter faecalis was isolated from a stool sample of a patient and was found to possess NDM-1 carbapenemase which confers resistance to carbapenem antibiotics [32]. In this study, one isolate was identified as P. faecalis (from local mango) by PCR (Table 3). To our knowledge, this is the first report of isolation of this species from fresh produce.

Erwinia aphidicola was first isolated from the gut of pea aphid by Harada and coworkers [33]. In their study, biochemical tests showed that this species was the closest to Erwinia herbicola and Pantoea agglomerans but DNADNA hybridization separated it into a new species. Later on, this species was recognized as an important plant pathogen 
especially for beans [34]. In this study, the 3 isolates of E. aphidicola (from imported capsicum and cucumber) as identified by PCR were identified as Pantoea spp. by VITEK 2 and this could be because of their similarities based on biochemical reactions. Rahnella aquatilis, though is commonly present in vegetables [28], has been found to be a primary pathogen and was isolated from blood, sputum, urine, and stool [35]. In this study, R. aquatilis was isolated from carrot (Australia) and lettuce (Iran) (Table 2). Likewise, Serratia spp. are often present in vegetables [28] but a species such as Serratia marcescens (isolated from local tomato in this study) has been recognized as an important cause of nosocomial infections [36]. Serratia liquefaciens was also found to cause bloodstream infection [37]. Citrobacter freundii, isolated from tomato, Netherlands, in this study, was reported to cause nosocomial bacteremia [38]. Raoultella planticola (isolated from cabbage, Netherlands) was found to cause wound infection [39].

E. coli is considered a better sanitary indicator than Enterobacteriaceae [28] where its presence indicates recent fecal contamination [30]. Unlike Österblad and colleagues [40] who rarely found $E$. coli in the examined 137 vegetable samples, E. coli was the most encountered species in this study properly due to its selective isolation on TBX medium. According to Public Health Leadership Society [41], fresh produce with $E$. coli count of $\geq 2 \log \mathrm{CFU} \mathrm{g}^{-1}$ is considered unsatisfactory. In this study, local cabbage and radish and imported radish contained this unsatisfactory level (Figure 1). In the current study, prevalence of $E$. coli in local and imported vegetables (33\%, $n=18$ and 15\%, $n=27$, resp., or $22 \%$ in all vegetables) is greater than what was found by Abadias and coworkers [28] in whole vegetables $(7 \%, n=28)$. The count of $E$. coli isolated at $44^{\circ} \mathrm{C}$ was less than the count at $30^{\circ} \mathrm{C}$ (Figure 1) indicating that, for direct counting of $E$. coli at $44^{\circ} \mathrm{C}$ on TBX, it would be better to preincubate plates at $30^{\circ} \mathrm{C}$ in order to resuscitate any injured cells.

$S$. aureus was found only in local radish with a mean count of $2.5 \log \mathrm{CFU} \mathrm{g}^{-1}$. It was reported that high levels of $S$. aureus of $>4 \log \mathrm{CFU} \mathrm{g}^{-1}$ might indicate enterotoxin production [14]. However, other researchers [42] reported that $S$. aureus was attributed to be the cause of a food poisoning outbreak in a hotel in Japan in 2005 where pickled radish was one of the sources that $S$. aureus was isolated from. The counts of this pathogen in radish, sashimi, and frozen crab were $1.7,1.7$, and 2.0 $\log \mathrm{CFU} \mathrm{g}^{-1}$, respectively, but its enterotoxin was found in a vomit sample indicating that isolation of pathogens from foods is significant, even at low levels, as some of them might proliferate in the food products if they are not kept at proper temperature $\left(1-5^{\circ} \mathrm{C}\right.$ for fresh fruits and vegetables) [28].

Similar to previous findings [43], our results showed that more vegetable samples $(\mathrm{LV}=38.9 \%$, IV $=48.1 \%)$ harbor Enterococcus than fruits $(\mathrm{LF}=28.6 \%, \mathrm{IF}=15.4 \%)$. Enterococcus spp. are involved in food intoxication and in spreading antibiotic resistance through the food chain and they are a leading cause of nosocomial infections [15] where E. faecalis and E. faecium cause the majority of them [43]. Enterococcus was isolated from all types of the tested fruits and vegetables (local and/or imported) except banana, pomegranate, carrot, and capsicum (Table 1). The highest counts of Enterococcus were found in local cabbage followed by local papaya ( 4.9 and $4.6 \log \mathrm{CFU} \mathrm{g}^{-1}$, resp., Figure 1). The presence of Enterococcus indicates fecal contamination [30] that might not be recent as they can persist for long time in the environment. However, besides gastrointestinal tract of animals and humans, this ubiquitous organism can be found in soil and on plants but identification of species might help in discriminating the source of Enterococcus. E. faecalis and E. faecium might be a better indicator of human fecal contamination than Enterococcus casseliflavus and Enterococcus mundtii that are more prevalent in environment [44]. In this study, E. faecalis was isolated from lettuce imported from Jordan and Iran and from radish, mango, and papaya produced in Oman while E. faecium was isolated from cabbage produced in Oman and from lettuce imported from Jordan. In other studies, E. faecalis was isolated from lettuce, radish, tomato, apple, cucumber, potato, sprouts, and carrot while E. faecium was isolated from dates, lettuce, tomato, and soy product $[15,43]$.

Similar to the result of others [43], E. casseliflavus was the most common species of Enterococcus (13 isolates, Table 2). Three isolates of Enterococcus ludwigii (capsicum, cucumber (UAE), tomato (Oman)), 1 isolate of Enterococcus hirae (papaya, Oman), and 1 isolate of Enterococcus raffinosus (dates, Oman) were found. Three species within the genus of Enterococcus that were not similarly identified by VITEK 2 and PCR are not included in the VITEK 2 latest version database including E. mundtii (isolates numbers 20, 31, 33, and 36), E. sulfureus (isolates numbers 21 and 27), and E. gilvus (isolate number 45). E. hirae and E. mundtii were isolated previously from different fruits and vegetables [43]. It was shown that genetic exchange of virulence determinants can occur between food and clinical isolates of E. faecium [45]. In fact, contaminated food might pose a risk and be a source for nosocomial infections [46].

Table 4 summarizes some bacteria that were previously reported to cause infections in human and that were isolated in the present study from fresh produce. Their sources could be environmental, food, or unknown. Clearly, these bacteria can gain access to critical sites in the body and establish infections. Many of them are considered as opportunistic pathogens capable of establishing infections in immunocompromised individuals. However, there are some sporadic cases where they can act as primary pathogens and thus cause infections in immunocompetent healthy people. Moreover, it is possible that opportunistic pathogens might emerge as important pathogens in future [3]. Determining the microbial quality of fresh produce served in hospitals would be of particular importance because translocation of pathogenic or opportunistic pathogens either to immunocompromised patients or to other environments in the hospitals might give these bacteria and/or their pathogenicity genetic determinants a better chance to be involved in the disease process.

Phylogenetic analysis showed grouping of most bacterial isolates with the reference strains obtained from NCBI, except for few species mainly from the Enterobacteriaceae. Members within Enterobacteriaceae have close genetic relationships 
TABLE 4: Case reports for bacterial infections caused by bacteria listed in Table 2 as presented in the literature.

\begin{tabular}{lccc}
\hline Bacteria & Specimen of isolation & Country \\
\hline Citrobacter freundii & Blood, urine & USA, South Africa \\
Enterobacter amnigenus & Eye & USA \\
Enterobacter asburiae & Blood & South Africa \\
Enterobacter cloacae & Stool & USA \\
Enterobacter hormaechei & Blood/trachea, nasopharynx/rectum & USA \\
Enterobacter ludwigii & Bone & India \\
Enterococcus casseliflavus & Cerebrospinal fluid & Italy \\
Enterococcus faecalis & Blood & South Africa \\
Enterococcus faecium & Cerebrospinal fluid & USA \\
Enterococcus hirae & Blood & France \\
Enterococcus raffinosus & Pelvic hematoma & Germany \\
Escherichia coli & Stool & USA \\
Klebsiella oxytoca & Stool & Austria \\
Klebsiella pneumoniae & Urine/liver, trachea & [50] \\
Pantoea agglomerans & Blood & USA, South Africa \\
Rahnella aquatilis & Blood & Italy \\
Raoultella planticola & Italy \\
Serratia liquefaciens & Beritoneal fluid, soft tissue, wound & {$[54]$} \\
Serratia marcescens & Eye & [55] \\
Staphylococcus aureus & Blood & [56] \\
\hline
\end{tabular}

and species often give polyphyletic groups in trees constructed using 16S rRNA sequences [63-65]. The 5 isolates of $S$. aureus were grouped together with a very high bootstrap support (100\%, Figure 4). Likewise, it was shown that sequencing of $16 \mathrm{~S}$ rRNA gene could be accurately used to generate phylogenetic relationships of the genus Staphylococcus [66]. Sequencing of $16 \mathrm{~S}$ rRNA gene gave good discrimination of the genus Enterococcus into 8 clusters, namely, E. faecium, E. hirae, E. mundtii, E. gilvus, E. raffinosus, E. casseliflavus, E. faecalis, and E. sulfureus (Figure 5, bootstrap percentages 50100). Similar discrimination of the genus Enterococcus was previously shown by sequencing $16 \mathrm{~S}$ rRNA and rpoA genes [67].

Although bacteria can contaminate fresh produce at any stage from farm to fork, in the current study, some samples were peeled and many were obtained in their original packages which may suggest contamination from the original countries. No relationship was found between clustering of the isolates based on the 16S rRNA gene and the countries or commodities from which they were obtained. Thus, circulation of these bacterial species among different countries cannot be ruled out and this may raise concerns about the role played by quarantine in limiting spread of human and plant pathogens via agricultural commodities. However, more epidemiological studies should be done specifically for each species taking into account increasing the number of isolates and further characterizing the strains in order to establish some relationships between the different genotypes.

In conclusion, this study analyzed for the first time the microbial load of some fresh fruits and vegetables in Oman at the point of retail sale. The presence of high counts of APC and Enterobacteriaceae as well as fecal bacteria indicates that the hygienic conditions of fruits and vegetables in Oman are not satisfactory and should be improved. Understanding the complex microbial ecosystem that is unique for each produce in a given country would be important to establish fully controlled systems for fruits and vegetables that can be applied during harvest, production, distribution, and marketing aimed at controlling spoilage and pathogenic microbes. The presence of $S$. aureus, possible pathogenic enterococci, and E. coli as well as other opportunistic and emerging pathogens in the examined fresh fruits and vegetables requires further investigation of virulence determinants which might be important in future for tracking their pathogenicity evolution.

\section{Conflict of Interests}

The authors declare that there is no conflict of interests regarding the publication of this paper.

\section{Acknowledgment}

The authors thank Sultan Qaboos University for providing financial support for this study.

\section{References}

[1] V. Prasanna, T. N. Prabha, and R. N. Tharanathan, "Fruit ripening phenomena-an overview," Critical Reviews in Food Science and Nutrition, vol. 47, no. 1, pp. 1-19, 2007.

[2] Y.-L. Lee, T. Cesario, Y. Wang, E. Shanbrom, and L. Thrupp, "Antibacterial activity of vegetables and juices," Nutrition, vol. 19, no. 11-12, pp. 994-996, 2003. 
[3] G. Berg, A. Erlacher, K. Smalla, and R. Krause, "Vegetable microbiomes: is there a connection among opportunistic infections, human health and our 'gut feeling'?" Microbial Biotechnology, vol. 7, no. 6, pp. 487-495, 2014.

[4] C. A. Lozupone, J. I. Stombaugh, J. I. Gordon, J. K. Jansson, and R. Knight, "Diversity, stability and resilience of the human gut microbiota," Nature, vol. 489, no. 7415, pp. 220-230, 2012.

[5] A. N. Olaimat and R. A. Holley, "Factors influencing the microbial safety of fresh produce: a review," Food Microbiology, vol. 32, no. 1, pp. 1-19, 2012.

[6] L. R. Beuchat, "Ecological factors influencing survival and growth of human pathogens on raw fruits and vegetables," Microbes and Infection, vol. 4, no. 4, pp. 413-423, 2002.

[7] S. A. Hassan, A. D. Altalhi, Y. A. Gherbawy, and B. A. ElDeeb, "Bacterial load of fresh vegetables and their resistance to the currently used antibiotics in Saudi Arabia," Foodborne Pathogens and Disease, vol. 8, no. 9, pp. 1011-1018, 2011.

[8] S. S. Al-Abri, A. K. Al-Jardani, M. S. Al-Hosni, P. J. Kurup, S. AlBusaidi, and N. J. Beeching, "A hospital acquired outbreak of Bacillus cereus gastroenteritis, Oman," Journal of Infection and Public Health, vol. 4, no. 4, pp. 180-186, 2011.

[9] S. Hauswaldt, M. Nitschke, F. Sayk, W. Solbach, and J. K.M. Knobloch, "Lessons learned from outbreaks of Shiga toxin producing Escherichia coli," Current Infectious Disease Reports, vol. 15, no. 1, pp. 4-9, 2013.

[10] Centers for Disease Control and Prevention (CDC), 2014, http://www.cdc.gov/outbreaks/.

[11] J. W. Leff and N. Fierer, "Bacterial communities associated with the surfaces of fresh fruits and vegetables," PLoS ONE, vol. 8, no. 3, Article ID e59310, pp. 1-9, 2013.

[12] L. U. Opara, F. A. Al-Said, and A. Al-Abri, "Assessment of what the consumer values in fresh fruit quality: case study of Oman," New Zealand Journal of Crop and Horticultural Science, vol. 35, no. 2, pp. 235-243, 2007.

[13] K. Hammer, J. Gebauer, S. Al Khanjari, and A. Buerkert, "Oman at the cross-roads of inter-regional exchange of cultivated plants," Genetic Resources and Crop Evolution, vol. 56, no. 4, pp. 547-560, 2009.

[14] K. Nguz, J. Shindano, S. Samapundo, and A. Huyghebaert, "Microbiological evaluation of fresh-cut organic vegetables produced in Zambia," Food Control, vol. 16, no. 7, pp. 623-628, 2005.

[15] H. Abriouel, N. B. Omar, A. C. Molinos et al., "Comparative analysis of genetic diversity and incidence of virulence factors and antibiotic resistance among enterococcal populations from raw fruit and vegetable foods, water and soil, and clinical samples," International Journal of Food Microbiology, vol. 123, no. 1-2, pp. 38-49, 2008.

[16] S. N. Al-Bahry, M. A. Al-Zadjali, I. Y. Mahmoud, and A. E. Elshafie, "Biomonitoring marine habitats in reference to antibiotic resistant bacteria and ampicillin resistance determinants from oviductal fluid of the nesting green sea turtle, Chelonia mydas," Chemosphere, vol. 87, no. 11, pp. 1308-1315, 2012.

[17] K. Tamura, D. Peterson, N. Peterson, G. Stecher, M. Nei, and S. Kumar, "MEGA5: molecular evolutionary genetics analysis using maximum likelihood, evolutionary distance, and maximum parsimony methods," Molecular Biology and Evolution, vol. 28, no. 10, pp. 2731-2739, 2011.

[18] D. J. Reasoner and E. E. Geldreich, "A new medium for the enumeration and subculture of bacteria from potable water," Applied and Environmental Microbiology, vol. 49, no. 1, pp. 1-7, 1985.
[19] M. J. Allen, S. C. Edberg, and D. J. Reasoner, "Heterotrophic plate count bacteria-what is their significance in drinking water?" International Journal of Food Microbiology, vol. 92, no. 3, pp. 265-274, 2004.

[20] G. R. Siragusa, W. J. Dorsa, C. N. Cutter, G. L. Bennett, J. E. Keen, and M. Koohmaraie, "The incidence of Escherichia coli on beef carcasses and its association with aerobic mesophilic plate count categories during the slaughter process," Journal of Food Protection, vol. 61, no. 10, pp. 1269-1274, 1998.

[21] R. Ruimy, A. Brisabois, C. Bernede et al., "Organic and conventional fruits and vegetables contain equivalent counts of Gramnegative bacteria expressing resistance to antibacterial agents," Environmental Microbiology, vol. 12, no. 3, pp. 608-615, 2010.

[22] N. S. Al-Zoreky, "Antimicrobial activity of pomegranate (Punica granatum L.) fruit peels," International Journal of Food Microbiology, vol. 134, no. 3, pp. 244-248, 2009.

[23] S. M. S. Menezes, L. N. Cordeiro, and G. S. B. Viana, "Punica granatum (pomegranate) extract is active against dental plaque," Journal of Herbal Pharmacotherapy, vol. 6, no. 2, pp. 79-92, 2006.

[24] S. A. Al-Maiman and D. Ahmad, "Changes in physical and chemical properties during pomegranate (Punica granatum L.) fruit maturation," Food Chemistry, vol. 76, no. 4, pp. 437-441, 2002.

[25] P. H. Nhung, K. Ohkusu, N. Mishima et al., "Phylogeny and species identification of the family Enterobacteriaceae based on dnaJ sequences," Diagnostic Microbiology \& Infectious Disease, vol. 58, no. 2, pp. 153-161, 2007.

[26] S. Mathur and R. Singh, "Antibiotic resistance in food lactic acid bacteria-a review," International Journal of Food Microbiology, vol. 105, no. 3, pp. 281-295, 2005.

[27] K. Forslund, S. Sunagawa, J. R. Kultima et al., "Country-specific antibiotic use practices impact the human gut resistome," Genome Research, vol. 23, no. 7, pp. 1163-1169, 2013.

[28] M. Abadias, J. Usall, M. Anguera, C. Solsona, and I. Viñas, "Microbiological quality of fresh, minimally-processed fruit and vegetables, and sprouts from retail establishments," International Journal of Food Microbiology, vol. 123, no. 1-2, pp. 121-129, 2008.

[29] D. Jonas, B. Spitzmüller, F. D. Daschner, J. Verhoef, and S. Brisse, "Discrimination of Klebsiella pneumoniae and Klebsiella oxytoca phylogenetic groups and other Klebsiella species by use of amplified fragment length polymorphism," Research in Microbiology, vol. 155, no. 1, pp. 17-23, 2004.

[30] J. M. T. Hamilton-Miller and S. Shah, "Identity and antibiotic susceptibility of enterobacterial flora of salad vegetables," International Journal of Antimicrobial Agents, vol. 18, no. 1, pp. 81-83, 2001.

[31] C. Brady, I. Cleenwerck, S. Venter, T. Coutinho, and P. De Vos, "Taxonomic evaluation of the genus Enterobacter based on multilocus sequence analysis (MLSA): Proposal to reclassify E. nimipressuralis and E. amnigenus into Lelliottia gen. nov. as Lelliottia nimipressuralis comb. nov. and Lelliottia amnigena comb. nov., respectively, E. gergoviae and E. pyrinus into Pluralibacter gen. nov. as Pluralibacter gergoviae comb. nov. and Pluralibacter pyrinus comb. nov., respectively, E. cowanii, E. radicincitans, E. oryzae and E. arachidis into Kosakonia gen. nov. as Kosakonia cowanii comb. nov., Kosakonia radicincitans comb. nov., Kosakonia oryzae comb. nov. and Kosakonia arachidis comb. nov., respectively, and E. turicensis, E. helveticus and E. pulveris into Cronobacter as Cronobacter zurichensis nom. 
nov., Cronobacter helveticus comb. nov. and Cronobacter pulveris comb. nov., respectively, and emended description of the genera Enterobacter and Cronobacter," Systematic and Applied Microbiology, vol. 36, no. 5, pp. 309-319, 2013.

[32] P. Kämpfer, S. P. Glaeser, M. W. Raza, S. A. Abbasi, and J. D. Perry, "Pseudocitrobacter gen. nov., a novel genus of the Enterobacteriaceae with two new species Pseudocitrobacter faecalis sp. nov., and Pseudocitrobacter anthropi sp. nov, isolated from fecal samples from hospitalized patients in Pakistan," Systematic and Applied Microbiology, vol. 37, no. 1, pp. 17-22, 2014.

[33] H. Harada, H. Oyaizu, Y. Kosako, and H. Ishikawa, "Erwinia aphidicola, a new species isolated from pea aphid, Acyrthosiphon pisum," Journal of General and Applied Microbiology, vol. 43, no. 6, pp. 349-354, 1997.

[34] F. Marín, M. Santos, F. Carretero, J. A. Yau, and F. Diánez, "Erwinia aphidicola isolated from commercial bean seeds (Phaseolus vulgaris)," Phytoparasitica, vol. 39, no. 5, pp. 483-489, 2011.

[35] K. Tash, "Rahnella aquatilis bacteremia from a suspected urinary source," Journal of Clinical Microbiology, vol. 43, no. 5, pp. 2526-2528, 2005.

[36] A. Hejazi and F. R. Falkiner, "Serratia marcescens," Journal of Medical Microbiology, vol. 46, no. 11, pp. 903-912, 1997.

[37] L. A. Grohskopf, V. R. Roth, D. R. Feikin et al., "Serratia liquefaciens bloodstream infections from contamination of epoetin alfa at a hemodialysis center," The New England Journal of Medicine, vol. 344, no. 20, pp. 1491-1497, 2001.

[38] V. Drelichman and J. D. Band, "Bacteremias due to Citrobacter diversus and Citrobacter freundii: incidence, risk factors, and clinical outcome," Archives of Internal Medicine, vol. 145, no. 10, pp. 1808-1810, 1985.

[39] B. Nada and M. Areej, "Raoultella planticola, a central venous line exit site infection," Journal of Taibah University Medical Sciences, vol. 9, no. 2, pp. 158-160, 2014.

[40] M. Österblad, O. Pensala, M. Peterzéns, H. Heleniusc, and P. Huovinen, "Antimicrobial susceptibility of Enterobacteriaceae isolated from vegetables," Journal of Antimicrobial Chemotherapy, vol. 43, no. 4, pp. 503-509, 1999.

[41] R. J. Gilbert, J. de Louvois, T. Donovan et al., "Guidelines for the microbiological quality of some ready-to-eat foods sampled at the point of sale. PHLS Advisory Committee for Food and Dairy Products," Communicable Disease and Public Health, vol. 3, no. 3, pp. 163-167, 2000.

[42] S. Kuramoto, H. Kodama, K. Yamada et al., "Food poisoning attributable to Staphylococcus aureus deficient in all of the staphylococcal enterotxoin gene so far reported," Japanese Journal of Infectious Diseases, vol. 59, no. 5, p. 347, 2006.

[43] L. L. McGowan, C. R. Jackson, J. B. Barrett, L. M. Hiott, and P. J. Fedorkacray, "Prevalence and antimicrobial resistance of enterococci isolated from retail fruits, vegetables, and meats," Journal of Food Protection, vol. 69, no. 12, pp. 2976-2982, 2006.

[44] A. B. Boehm and L. M. Sassoubre, "Enterococci as indicators of environmental fecal contamination," in Enterococci: From Commensals to Leading Causes of Drug Resistant Infections, M. S. Gilmore, D. B. Clewell, Y. Ike et al., Eds., Massachusetts Eye and Ear Infirmary, Boston, Mass, USA, 2014.

[45] T. J. Eaton and M. J. Gasson, "Molecular screening of Enterococcus virulence determinants and potential for genetic exchange between food and medical isolates," Applied and Environmental Microbiology, vol. 67, no. 4, pp. 1628-1635, 2001.
[46] T. G. Emori and R. P. Gaynes, "An overview of nosocomial infections, including the role of the microbiology laboratory," Clinical Microbiology Reviews, vol. 6, no. 4, pp. 428-442, 1993.

[47] K. Gqunta, J. van Wyk, P. Ekermans, C. Bamford, C. Moodley, and S. Govender, "First report of an IMI-2 carbapenemaseproducing Enterobacter asburiae clinical isolate in South Africa,' Southern African Journal of Infectious Diseases, vol. 30, no. 1, pp. 34-35, 2015.

[48] C. Westerfeld, G. N. Papaliodis, I. Behlau, M. L. Durand, and L. Sobrin, "Enterobacter amnigenus endophthalmitis," Retinal Cases \& Brief Reports, vol. 3, no. 4, pp. 409-411, 2009.

[49] A. W. Paton and J. C. Paton, "Enterobacter cloacae producing a Shiga-like toxin II-related cytotoxin associated with a case of hemolytic-uremic syndrome," Journal of Clinical Microbiology, vol. 34, no. 2, pp. 463-465, 1996.

[50] P. N. Wenger, J. I. Tokars, P. Brennan et al., "An outbreak of Enterobacter hormaechei infection and colonization in an intensive care nursery," Clinical Infectious Diseases, vol. 24, no. 6, pp. 1243-1244, 1997.

[51] A. Khajuria, A. K. Praharaj, N. Grover, and M. Kumar, "First report of an Enterobacter ludwigii isolate coharboring NDM1 and OXA-48 carbapenemases," Antimicrobial Agents and Chemotherapy, vol. 57, no. 10, pp. 5189-5190, 2013.

[52] C. Iaria, G. Stassi, G. B. Costa, R. di Leo, A. Toscano, and A. Cascio, "Enterococcal meningitis caused by Enterococcus casseliflavus. First case report," BMC Infectious Diseases, vol. 5, article 3, 2005.

[53] C. Zeana, C. J. Kubin, P. Della-Latta, and S. M. Hammer, "Vancomycin-resistant Enterococcus faecium meningitis successfully managed with linezolid: Case report and review of the literature," Clinical Infectious Diseases, vol. 33, no. 4, pp. 477482, 2001.

[54] C. Poyart, T. Lambert, P. Morand et al., "Native valve endocarditis due to Enterococcus hirae," Journal of Clinical Microbiology, vol. 40, no. 7, pp. 2689-2690, 2002.

[55] B. S. Freyaldenhoven, G. Schlieper, R. Lütticken, and R. R. Reinert, "Enterococcus raffinosus infection in an immunosuppressed patient: case report and review of the literature," Journal of Infection, vol. 51, no. 3, pp. e121-e124, 2005.

[56] C. Högenauer, C. Langner, E. Beubler et al., "Klebsiella oxytoca as a causative organism of antibiotic-associated hemorrhagic colitis," The New England Journal of Medicine, vol. 355, no. 23, pp. 2418-2426, 2006.

[57] A. Elemam, J. Rahimian, and W. Mandell, "Infection with panresistant Klebsiella pneumoniae: a report of 2 cases and a brief review of the literature," Clinical Infectious Diseases, vol. 49, no. 2, pp. 271-274, 2009.

[58] M. C. Liberto, G. Matera, R. Puccio, T. Lo Russo, E. Colosimo, and E. Focà, "Six cases of sepsis caused by Pantoea agglomerans in a teaching hospital," New Microbiologica, vol. 32, no. 1, pp. 119-123, 2009.

[59] M. S. Alves, L. W. Riley, and B. M. Moreira, "A case of severe pancreatitis complicated by Raoultella planticola infection," Journal of Medical Microbiology, vol. 56, no. 5, pp. 696-698, 2007.

[60] K. O' Connell, J. Kelly, and U. NiRiain, "A rare case of softtissue infection caused by Raoultella planticola," Case Reports in Medicine, vol. 2010, Article ID 134086, 2 pages, 2010.

[61] R. A. Equi and W. R. Green, "Endogenous Serratia marcescens endophthalmitis with dark hypopyon: a case report and review," Survey of Ophthalmology, vol. 46, no. 3, pp. 259-268, 2001. 
[62] C. Tascini, A. Di Paolo, M. Polillo et al., "Case report of a successful treatment of methicillin-resistant Staphylococcus aureus (MRSA) bacteremia and MRSA/vancomycin-resistant Enterococcus faecium cholecystitis by daptomycin," Antimicrobial Agents and Chemotherapy, vol. 55, no. 5, pp. 2458-2459, 2011.

[63] P. H. Nhung, K. Ohkusu, N. Mishima et al., "Phylogeny and species identification of the family Enterobacteriaceae based on dnaJ sequences," Diagnostic Microbiology and Infectious Disease, vol. 58, no. 2, pp. 153-161, 2007.

[64] F. Rezzonico, T. H. Smits, E. Montesinos, J. E. Frey, and B. Duffy, "Genotypic comparison of Pantoea agglomerans plant and clinical strains," BMC Microbiology, vol. 9, article 204, 2009.

[65] C. Spröer, U. Mendrock, J. Swiderski, E. Lang, and E. Stackebrandt, "The phylogenetic position of Serratia, Buttiauxella and some other genera of the family Enterobacteriaceae," International Journal of Systematic Bacteriology, vol. 49, no. 4, pp. 14331438, 1999.

[66] T. Takahashi, I. Satoh, and N. Kikuchi, "Phylogenetic relationships of 38 taxa of the genus Staphylococcus based on 16S rRNA gene sequence analysis," International Journal of Systematic Bacteriology, vol. 49, no. 2, pp. 725-728, 1999.

[67] S. M. Naser, F. L. Thompson, B. Hoste et al., "Application of multilocus sequence analysis (MLSA) for rapid identification of Enterococcus species based on rpoA and pheS genes," Microbiology, vol. 151, no. 7, pp. 2141-2150, 2005. 

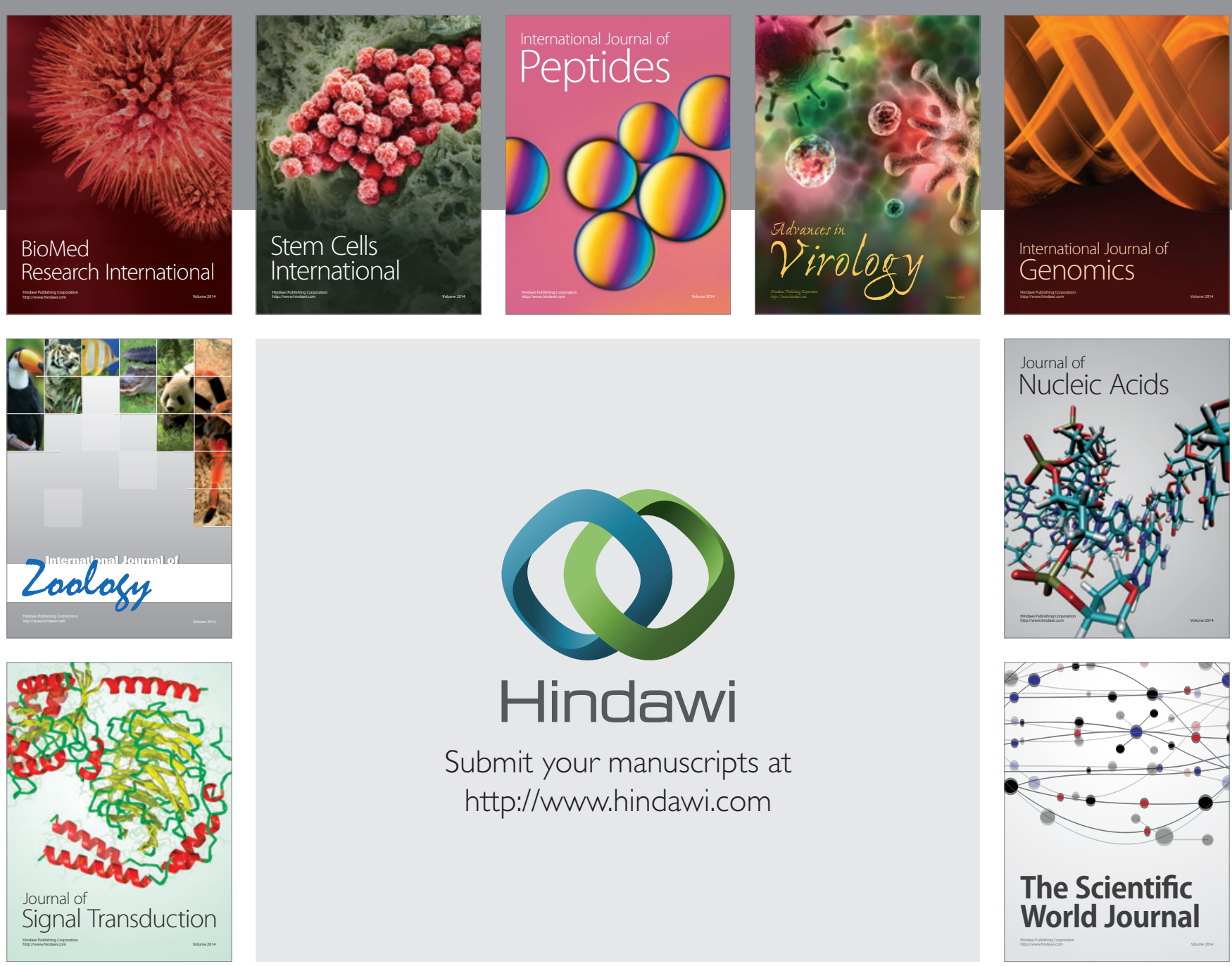

Submit your manuscripts at

http://www.hindawi.com
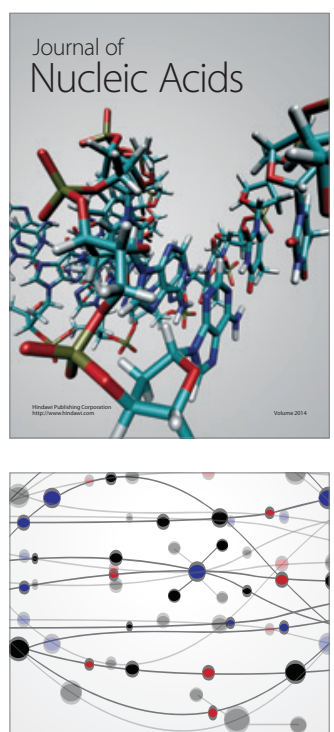

The Scientific World Journal
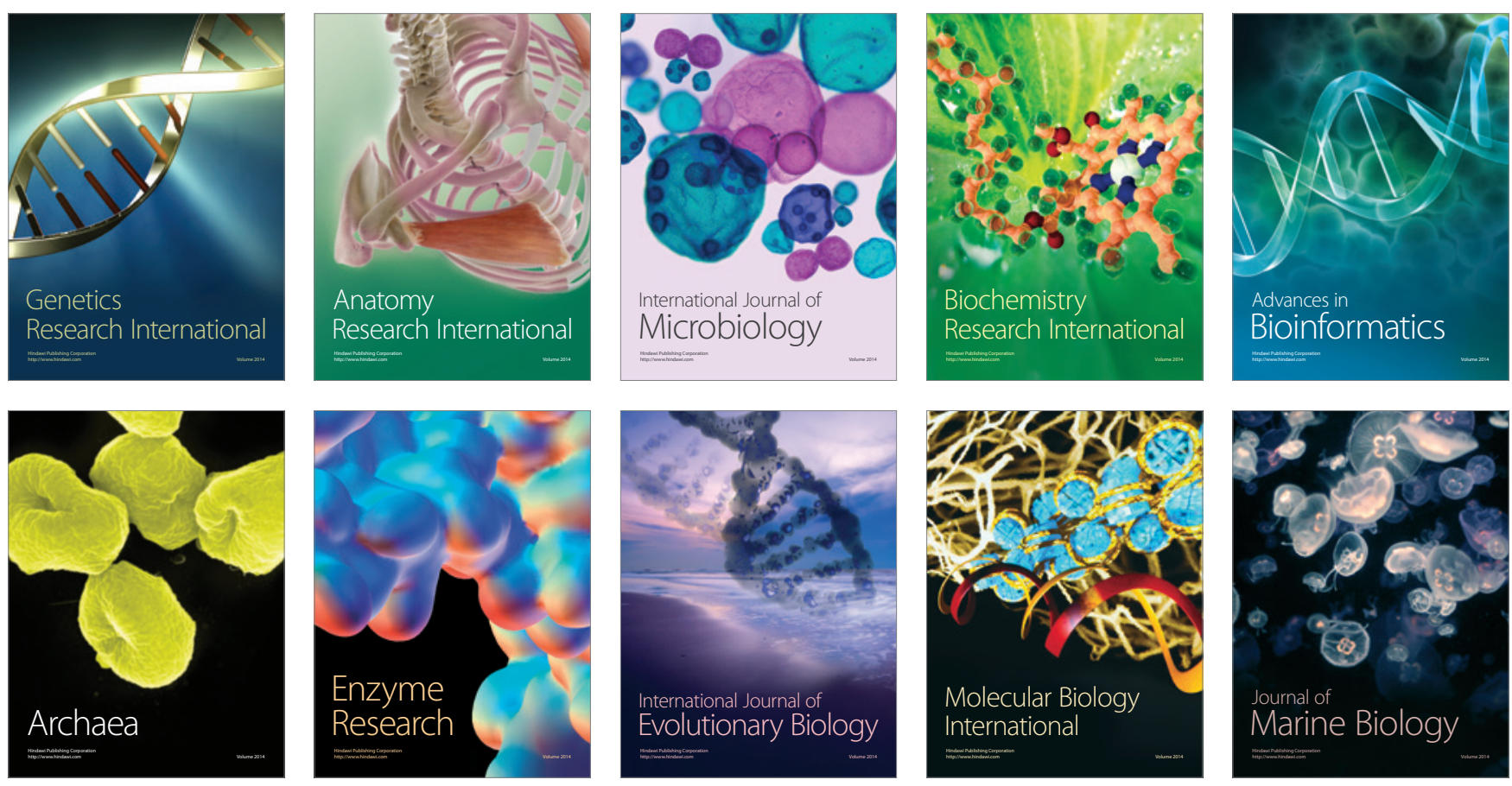